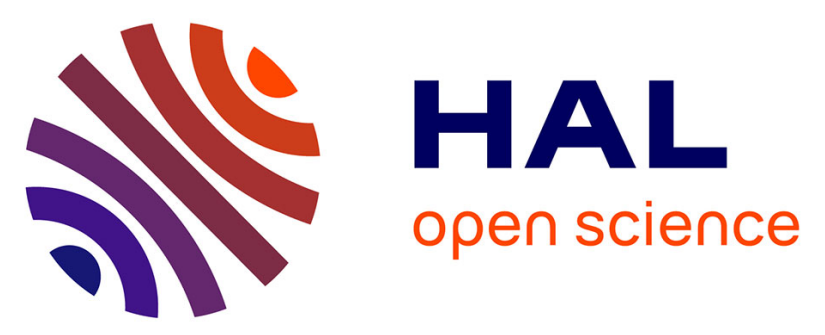

\title{
Decoupled PQ control Applied to a Multicellular Parallel Inverter for Grid-connected Photovoltaic System
}

Chabakata Mahamat, Mickael Petit, Rym Marouani, Cyrille Gautier, Abdelkader Mami, François Costa

\section{To cite this version:}

Chabakata Mahamat, Mickael Petit, Rym Marouani, Cyrille Gautier, Abdelkader Mami, et al.. Decoupled PQ control Applied to a Multicellular Parallel Inverter for Grid-connected Photovoltaic System - 17th International Conference on Sciences and Techniques of Automatic Control and Computer Engineering (STA), Lab-STA, ATTNA, Dec 2016, Sousse, Tunisia. 10.1109/STA.2016.7952002 . hal-01676140

\section{HAL Id: hal-01676140 \\ https://hal.science/hal-01676140}

Submitted on 5 Jan 2018

HAL is a multi-disciplinary open access archive for the deposit and dissemination of scientific research documents, whether they are published or not. The documents may come from teaching and research institutions in France or abroad, or from public or private research centers.
L'archive ouverte pluridisciplinaire HAL, est destinée au dépôt et à la diffusion de documents scientifiques de niveau recherche, publiés ou non, émanant des établissements d'enseignement et de recherche français ou étrangers, des laboratoires publics ou privés. 


\title{
Decoupled PQ control Applied to a Multicellular Parallel Inverter for Grid-connected Photovoltaic System
}

\author{
Chabakata MAHAMAT ${ }^{1,2}$, Mickael PETIT ${ }^{4}$, Rym MAROUANI ${ }^{2}$, Cyrille GAUTIER $^{3}$ \\ Abdelkader MAMI ${ }^{2}$ and François COSTA $^{5}$. \\ ${ }^{1}$ Université de Paris-Saclay, Ecole Normale Supérieure (ENS) de Paris-Saclay, Laboratoire SATIE, France \\ ${ }^{2}$ Université de Tunis El Manar, Faculté des Sciences de Tunis, Laboratoire LACS-ENIT, Tunisie \\ ${ }^{3}$ Université Paris Ouest Nanterre La Défense, IUT de ville d'Avray, Laboratoire SATIE, France \\ ${ }^{4}$ Conservatoire national des arts et métiers (Cnam) Paris, CNRS, Laboratoire SATIE, France \\ ${ }^{5}$ Université de Paris Est Créteil, ESPE de Créteil, Laboratoire SATIE, France. \\ emails: chabakata.mahamat@satie.ens-cachan.fr, mickael.petit@satie.ens-cachan.fr, rimarouani@yahoo.fr, \\ cyrille.gautier@satie.ens-cachan.fr,abdelkader.mami@fst.utm.tn,francois.costa@satie.ens-cachan.fr
}

\begin{abstract}
This paper presents the decoupled active and reactive power control (PQ control), using a Phase-Locked Loop (PLL) for synchronization, and applied to the control of Multicellular Parallel Inverter (MPI) for a grid-connected Photovoltaic (PV) system. We explain the value of this multicellular structure of inverter compared to a conventional inverter. We also present and discuss the simulation results obtained using the Matlab software (simulink and simpowersystems).
\end{abstract}

Keywords - decoupled $P Q$ control, $P L L$, Multicellular Parallel Inverter, $L$ filter.

\section{INTRODUCTION}

Static converters play an essential role in converting and preserving the quality of electrical energy in grid-connected photovoltaic $(P V)$ systems. Indeed, maximizing the power transfer from the Photovoltaic Generator $(P V G)$ to the electrical grid and optimizing the system dynamics both depend on the static converter technology used and its control algorithms [1]. In the architecture of a classical PV system, a $L C L$ filter is often used to connect the inverter to the utility grid in order to obtain a good attenuation of high frequency harmonics generated by the inverter [1], [2]. However, the use of the $L C L$ filter complicates the control, due to the increase of the order of the filter. Insofar as it is no longer possible to control the system using conventional controllers (PI: Proportional Integral), we must use other types of commands such as cascade controllers etc.

In order to control this system with conventional PI controllers, we can use a $\mathrm{L}$ filter but in this case, we must make a compromise between the quality of the energy (the good attenuation of harmonics) and the system dynamics (the speed of the system). Indeed, with classical inverters and L filters, it is necessary to increase the size of the inductor $L$ to obtain a sufficient harmonic attenuation. However, this causes an increase in the size of the filter, its price and the response time of the system [2].

To solve this problem, we propose a new architecture of $P V$ system with a Multicellular Parallel Inverter $(M P I)$ and a L filter to facilitate the control of the system. In addition, the use of an innovative structure using a multicellular converter in this domain should allow a gain in volume of the filter, in system reliability, and in quality of energy. The objective of this work is to analyze the $P V$ system with parallel multicellular structure and to show that this is a very interesting structure compared to the conventional solution. We are particularly interested in control and sizing of this system, in a context of use in Africa (in Chad) where the cost, the reliability and the maintenance issues of the system should be taken into account. The grid considered is low voltage $(230 \mathrm{~V}, 50 \mathrm{~Hz})$ in which a power of a few kilowatts $(\mathrm{kW})$, depending on the number of $P V$ panel, is injected.

This work is organized around the following sections: section II describes the system under study, section III presents the study of the inverter including the principle of this inverter and the sizing of passive elements, section $I V$ presents the modeling and control of the system. Finally, section $V$ presents the simulation results and interpretations.

\section{DESCRIPTION OF THE SYSTEM}

Figure 1 shows the proposed architecture of the grid connected $P V$ system.

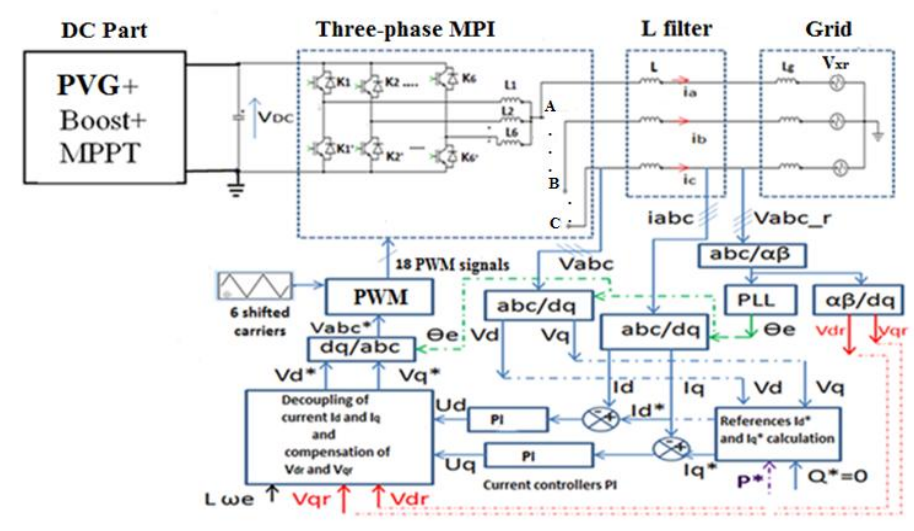

Figure 1. Diagram of the grid-connected $P V$ system and its control

The system is composed of two parts: a continuous part $(D C)$ and an alternative part $(A C)$. The $D C$ part composed of the $P V G$, the boost converter, and the Maximum Power Point Tracking (MPPT) algorithm, will not be studied in this paper. We are only interested in the $A C$ part composed of the Multicellular Parallel Inverter (MPI), the $L$ filter and the utility grid. The system is controlled by decoupled $P Q$ control and synchronized by PLL (Phase-Locked Loop) which is based on the Park transform. 


\section{STUDY OF THE CONSIDERED INVERTER}

1) Principle of the Multicellular Parallel Inverter

The simplified diagram of the three-phase MPI with six interleaved magnetically independent cells is shown in Figure 2. Where $x=a, b, c$ is the name of the considered phase of the inverter.

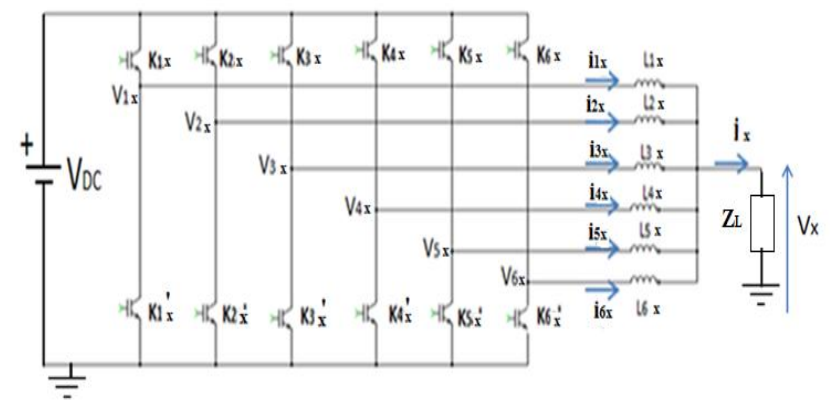

Figure 2. Three-phase multicellular inverter with 6 interleaved cells

Three-phase MPIs with six interleaved cells have already been studied in [3] and [4], where the authors were interested in the structure with six magnetically coupled cells. The coupling of the inductors allows reducing the phase ripple current and further miniaturizing the entire inverter and output filter [4]. In aeronautic and railway applications, it is important to consider the constraints of volume and weight to obtain a more compact converter. In a PV application, these constraints are less important. Furthermore, if the cells are magnetically coupled, in case of failure on one of the cells, all other cells are affected [3]. This problem reduces the reliability of the system. Here, we consider the interleaved structure with independent inductors for more reliability of the system. In addition, this structure also offers a reduction of the overall volume of the filter by offering a large increase in the apparent frequency of the output current ripple. Furthermore, this technique allows accelerating the system by decreasing the response time of the converter [4]. Its principle is based on the combination of the current ripple of each cell to obtain a low output current ripple [3], [4].

As in a conventional inverter, the two switches of the same inverter arm are controlled complementarily.

$K_{i x}=\overline{K_{i x}^{\prime}}$; where $i=\{1,2, \ldots, 6\}$ and $x=\{a, b, c\}$.

The six different switching cells are shifted by $\frac{2 \pi}{6}$ and controlled with the same duty cycle [3], [4]. The three phases of the inverter $(a, b, c)$ are also shifted by $\frac{2 \pi}{3}$.

To simplify, the study of the three-phase inverter can be reduced to a single phase. Figure 3 shows the waveforms of a one phase of the MPI with six independent interleaved cells when a RL load is connected (For specifications of this MPI + load, Cf. Table I).

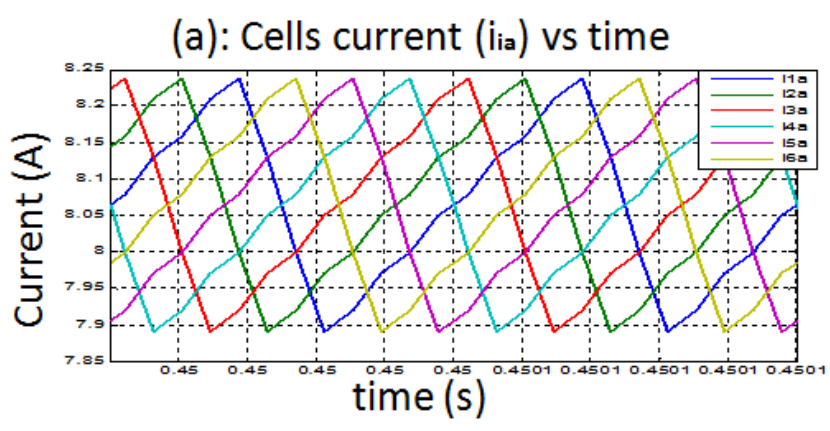

(b): Output current ( $\mathrm{i}_{\mathrm{a}}$ ) vs time

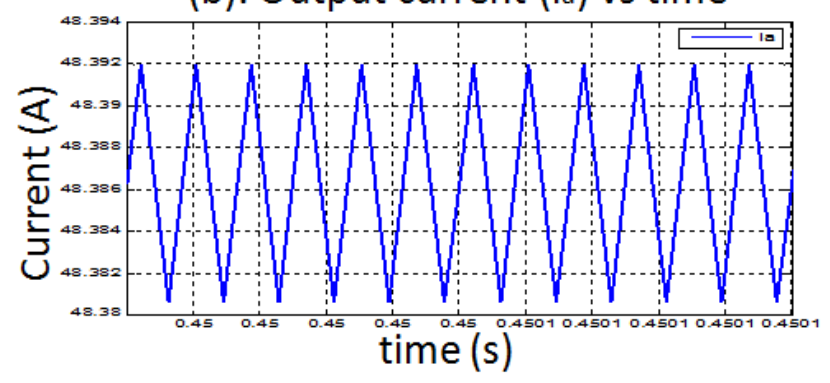

(c): Output voltage $\left(\mathrm{V}_{\mathrm{a}}\right)$ vs time

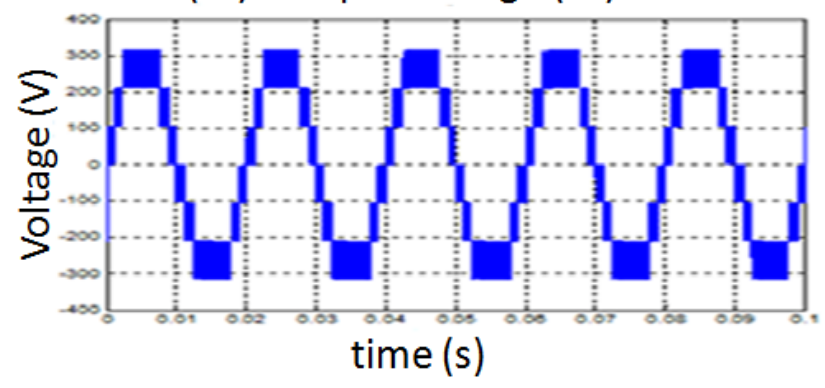

Figure 3. Waveforms of the MPI with six cells

It can be seen in figure 3 ( $a$ and $b$ ) that the output current is effectively equal to the sum of the cell currents. Furthermore, the frequency of the ripple output current is six time higher than that the ripple current of one cell. In addition, dividing the output current allows reducing the current constraints on the semiconductor switches of the inverter. However, the voltage constraints are the same as the conventional structure [3].

In figure 3.c, we see that the waveform of the voltage is more sinusoidal than the waveform of classical two levels inverter (not presented here) and has seven levels voltage. So the inverter with six interleaved cells can be also called seven levels voltage inverter. Comparing with the usual obtained with a classical inverter, the fact that the voltage is more sinusoidal makes it easier to filter. We can therefore use small caliber passive elements to realize the output filter.

2) Sizing of passive elements

Passive elements have been dimensioned in Table I.

We can see in table I that, in the case of interleaved inverter, the ripple output current is divided by $\operatorname{six}(q=6$ : the number of interleaved cells) compared to the classical inverter.

Using table I and neglecting the resistances of copper, we compare the filtering volume as follows: 
* In general [11]:

- Energy: $W=\frac{1}{2} L I_{\max }{ }^{2}$

- Volume: Vol $\propto W^{3 / 4}$

So Vol $\propto \frac{1}{2} L^{3 / 4} I_{\max }{ }^{3 / 2}$

* Three-phase classical inverter:

$$
V l_{1} \propto 3 \cdot \frac{1}{2} \cdot L_{f}{ }^{3 / 4} \cdot I_{o_{-} \max }{ }^{3 / 2}
$$

* Three-phase MPI six interleaved cells:

$\mathrm{Vol}_{2} \propto 3 \cdot \frac{1}{2} \cdot L_{f}^{3 / 4 I_{o_{-} \max }}{ }^{3 / 2}+3 q \cdot \frac{1}{2} \cdot L_{i x}{ }^{3 / 4}\left(\frac{I_{o_{-} \max }}{q}\right)^{3 / 2}$

By (4) and (5), the volume ratio is follows:

$\lambda=\frac{V o l_{2}}{V o l_{1}}=\left(\frac{L_{f}}{L_{f}}\right)^{3 / 4}+\left(\frac{L_{i x}}{L_{f}}\right)^{3 / 4} \cdot\left(\frac{1}{q 1 / 2}\right)=0.66$

Note: $\lambda<1 \Rightarrow \operatorname{Vol}_{2}<\operatorname{Vol}_{1}$

Thus, the volume is reduced.

TABLE I. SIZING OF THE ELEMENTS OF THE FILTER

\begin{tabular}{|c|c|c|c|c|}
\hline \multirow[b]{2}{*}{ Symbol } & \multirow[b]{2}{*}{ Parameter } & \multicolumn{2}{|c|}{ Value } & \multirow[b]{2}{*}{ Unit } \\
\hline & & $\begin{array}{c}\text { classical } \\
\text { inverter }\end{array}$ & $\begin{array}{l}M P I \\
(q=6)\end{array}$ & \\
\hline$P_{\max }$ & Maximum power & 5.2 & 5.2 & $\mathrm{~kW}$ \\
\hline$V_{D C}$ & DC bus voltage & 650 & 650 & $\mathrm{~V}$ \\
\hline $\mathrm{V}_{\mathrm{g}}$ & Grid RMS voltage & 230 & 230 & $\mathrm{~V}$ \\
\hline $\mathrm{L}_{\mathrm{g}}$ & Grid side inductor & 6.75 & 6.75 & $\mu \mathrm{H}$ \\
\hline $\mathrm{f}_{\mathrm{sw}}$ & Switching frequency & 20 & 20 & $\mathrm{kHz}$ \\
\hline $\mathrm{f}$ & Grid frequency & 50 & 50 & $\mathrm{~Hz}$ \\
\hline $\mathrm{I}_{\mathrm{o} \max }$ & Maximum output current & 10.66 & 10.66 & A \\
\hline $\mathrm{I}_{\mathrm{L} \text { max }}$ & Maximum phase current & 10.66 & 1.77 & $\mathrm{~A}$ \\
\hline$\Delta \mathrm{I}_{\text {phase }}$ & Ripple phase current & 2 & 2 & A \\
\hline$\Delta \mathrm{I}_{\mathrm{O}_{\text {} \max }}$ & Ripple output current & 2 & 0.33 & A \\
\hline $\mathrm{L}_{\mathrm{ix}}$ & Cell inductor & $\mathrm{x}$ & 5.5 & $\mathrm{mH}$ \\
\hline $\mathrm{L}_{\mathrm{f}}$ & Binding filter inductor & 5.5 & 1 & $\mathrm{mH}$ \\
\hline $\mathrm{R}_{\mathrm{ix}}$ & Cell side resistor & 0.5 & 0.5 & $\Omega$ \\
\hline$R_{f}$ & Binding filter resistor & 0.5 & 0.5 & $\Omega$ \\
\hline $\mathrm{R}_{\mathrm{g}}$ & Grid side resistor & 0.5 & 0.5 & $\mathrm{~m} \Omega$ \\
\hline
\end{tabular}

\section{MODELING AND CONTROL OF THE SYSTEM}

\section{1) Electrical model of the binding filter}

By considering the resistor of the copper windings of the inductors, the simplified equivalent diagram of the connecting filter is shown in Figure 4.

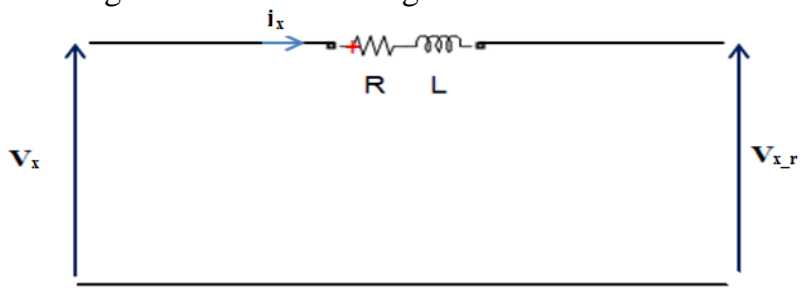

Figure 4. The equivalent circuit of the binding filter

2) Mathematical models of the binding filter Mathematical models of this diagram follow:

- In the $a b c$ frame:

$$
V_{x}=L \frac{d i_{x}}{d t}+R i_{x}+V_{x_{-} r}
$$

Where $V_{x}, V_{x \_r}$ and $i_{x}$ : the inverter voltage, the grid voltage and the grid current respectively. $R$ is the sum of the copper resistances of the filter and the grid $\left(R=R_{f}+R_{g}\right)$ whereas $L$ is the sum of the inductors $\left(L=L_{f}+L_{g}\right)$.

- $\quad$ In the Park frame:

$$
\frac{d}{d t}\left(\begin{array}{l}
I_{d} \\
I_{q}
\end{array}\right)=\left(\begin{array}{cc}
-\frac{R}{L} & \omega \\
-\omega & -\frac{R}{L}
\end{array}\right)\left(\begin{array}{l}
I_{d} \\
I_{q}
\end{array}\right)+\frac{1}{L}\left(\begin{array}{l}
V_{d}-V_{d r} \\
V_{q}-V_{q r}
\end{array}\right)
$$

$V_{d}, V_{d r}$ and,$I_{d}$ are the d-axis inverter voltage (in the Park frame), the grid voltage and the grid current respectively whereas $V_{q}, V_{q r}$ and $I_{q}$ are the $q$-axis components; $\omega$ is the pulsation $(\omega=2 \pi f)$.

By developing (8), (9) is obtained

$$
\left\{\begin{array}{l}
L \frac{d I_{d}}{d t}=-R I_{d}+L \omega I_{q}+V_{d}-V_{d r} \\
L \frac{d I_{q}}{d t}=-R I_{q}-L \omega I_{d}+V_{q}-V_{q r}
\end{array}\right.
$$

3) Transfer Function of the Filter

In equation (9), we set:

$$
\left\{\begin{array}{l}
U_{d}=L \omega I_{q}+V_{d}-V_{d r} \\
U_{q}=-L \omega I_{d}+V_{q}-V_{q r}
\end{array}\right.
$$

Using the Laplace transform we obtain:

$$
\left\{\begin{array}{l}
H_{d}(s)=\frac{I_{d}(s)}{U_{d}(s)}=\frac{1}{L s+R} \\
H_{q}(s)=\frac{I_{q}(s)}{U_{q}(s)}=\frac{1}{L s+R}
\end{array}\right.
$$

Since the filter transfer function is first order, conventional PI controllers are sufficient to control the system [9].The transfer function of the PI controller is given in (12).

$$
C(s)=k_{p 1}+\frac{k_{i 1}}{s}
$$

Where $s$ is the Laplace variable.

4) Current control Loop

The d-axis current control loop is shown in Figure 5. The same loop is also valid for the q-axis current (only the coupling term is different).

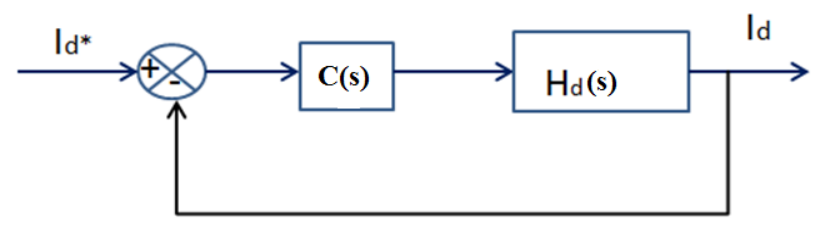

Figure 5. The d-axis current control loop

The open loop transfer function (FTBO) of this system is given in (13).

$$
F T B O(s)=C(s) \cdot H_{d}(s)=\frac{k_{p 1}+\frac{k_{i 1}}{s}}{L s+R}
$$

So the closed loop transfer function (FTBF) is follows:

$$
F T B F(s)=\frac{F T B O(s)}{1+F T B O(s)}=\frac{V_{D C}\left(k_{p 1} s+k_{i 1}\right) / L}{s^{2}+\left(\frac{R+k_{p 1}}{L}\right) s+\frac{k_{i 1}}{L}}
$$

5) Calculation of the PI parameters $\left(k_{p 1}, k_{i 1}\right)$

The calculation of parameters of the PI controller ( $k_{p 1}$ et $\left.k_{i 1}\right)$ is analytical. To determine these parameters, we remind the denominator of a system of second order in (15).

$$
s^{2}+2 z \omega_{i} s+\omega_{i}^{2}
$$


Where $z$, and $\omega_{\mathrm{i}}$ are the damping factor and the cut-off frequency, respectively. By identifying the denominator of (14) with (15), the parameters of the PI controller are obtained:

$$
\left\{\begin{array}{l}
k_{p 1}=2 z \omega_{i 1} L-R \\
k_{i 1}=L \omega_{i 1}^{2}
\end{array}\right.
$$

For $L=L_{f}+L_{g} \approx 1 \mathrm{mH}, R=R_{f}+R_{g} \approx 0.5 \Omega$ and $\mathrm{z}=$ 1 (to eliminate the oscillations),

we obtain:

$t_{i 1}=20 \mathrm{~ms}\left(\omega_{i 1}=\frac{1}{t_{i 1}}\right), k_{p 1}=0.5$ and $k_{i 1}=250$.

So the theoretical response time of the system is equal to $t_{i 1}=20 \mathrm{~ms}$.

\section{6) Decoupling and compensation}

The parameters of the $P I$ controller are calculated without considering the coupling of the $d$-axis $\left(I_{d}\right)$ and $q$-axis $\left(I_{q}\right)$ components of the current (see equation (9)). To control separately the d-axis current $I_{d}$ and the q-axis current $I_{q}$ and accordingly the active power $P$ and reactive power $Q$, it is necessary to decouple (9). That is to say, to eliminate the coupling terms $\left(L \omega I_{q}\right.$ and $\left.L \omega I_{d}\right)$ and compensate the $d$-axis and $q$-axis components of the grid voltage $\left(V_{d r}\right.$ et $\left.V_{q r}\right)$.

So just set:

$$
\left\{\begin{array}{l}
V_{d}{ }^{*}=U_{d}-L \omega I_{q}+V_{d r} \\
V_{q}{ }^{*}=U_{q}+L \omega I_{d}+V_{q r}
\end{array}\right.
$$

The control diagram of the system is shown in figure 6 .

The two PI controllers compare the current references $\left(I_{d q}{ }^{*}\right)$ with the output inverter current values $\left(I_{d q}\right.$ : measured current) and bring the necessary corrections to obtain a zero gap (zero static error). Then, the terms of disturbance (coupling terms and grid voltage) is removed to obtain a reference $\left(V_{d}{ }^{*}\right)$ equal to the maximum amplitude of the grid voltage and $\left(V_{q}{ }^{*}\right)$ equal to zero $\left(V_{d}{ }^{*}=230 \sqrt{2} \mathrm{~V}\right.$ and $\left.V_{q}{ }^{*}=0\right)$, when the system is synchronized by the PLL. Finally, the references $\left(V_{d q}{ }^{*}\right)$ are transformed using the inverse Park transform to obtain the references voltages in the $a b c$ frame $\left(V_{x}^{*}\right)$.

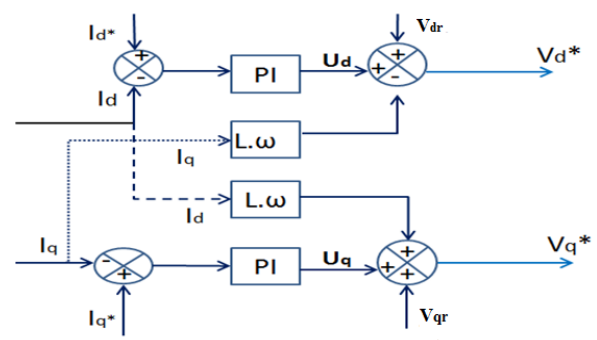

Figure 6. Diagram of the decoupled PQ Control

Each of these voltages is used as a reference voltage for the Pulse Width Modulation (PWM) blocks (see Figure 1).

7) Highlighting of the PWM (Pulse Width Modulation)

The principle of the PWM is based on comparing the lowfrequency fundamental signal (here $V_{x}{ }^{*}$ ) to a high-frequency signal (called carrier) to generate a PWM signal used to control an inverter arm. Here, for the same phase inverter, six different cells use the same fundamental signal but the carriers are shifted by $2 \pi / 6$. The fundamental frequency signal is equal to $f=50 \mathrm{~Hz}$ (grid frequency) whereas the frequency of the carrier is equal to $f s w=20 \mathrm{kHz}$ (switching frequency). The two switches of the same arm (cell) are controlled complementarily.

Figure 7 shows the details of the PWM block for one phase of the inverter. This figure is also valid for the other phases of the inverter but the three references voltages $\left(V_{x}^{*}\right)$ are shifted by $2 \pi / 3$. Each reference voltage is compared with six carriers which they are regularly shifted by $2 \pi / 6$.

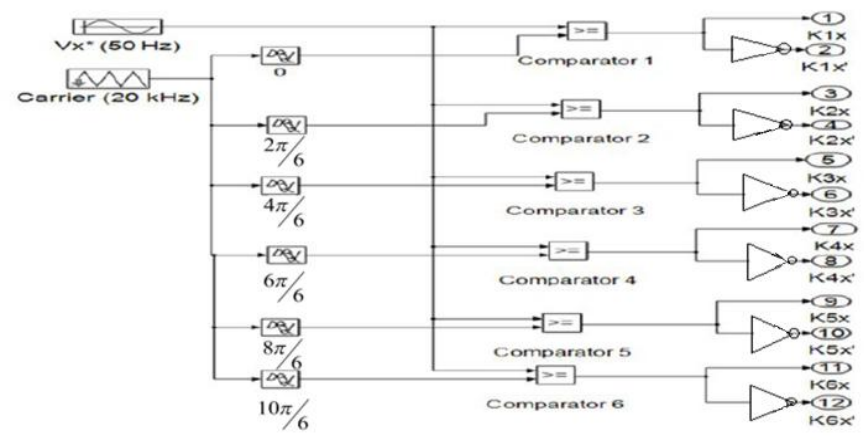

Figure 7. PWM control of one phase of the inverter

8) Calculation of the Current Reference

The active $(P)$ and reactive $(Q)$ power are written in the Park frame as follows:

$$
\left\{\begin{array}{l}
P=\frac{3}{2}\left(V_{d} I_{d}+V_{q} I_{q}\right) \\
Q=\frac{3}{2}\left(V_{q} I_{d}-V_{d} I_{q}\right)
\end{array}\right.
$$

We deduce the components of the current reference in (19).

$$
\left\{\begin{array}{l}
I_{d}{ }^{*}=\frac{2}{3}\left(\frac{P^{*} V_{d}+Q^{*} V_{q}}{V_{d}{ }^{2}+V_{q}{ }^{2}}\right) \\
I_{q}{ }^{*}=\frac{2}{3}\left(\frac{P^{*} V_{q}-Q^{*} V_{d}}{V_{d}{ }^{2}+V_{q}{ }^{2}}\right)
\end{array}\right.
$$

Where $P^{*}$ is the active power reference and $Q^{*}$ is the reactive power reference.

9) Phase Locked Loop (PLL)

To synchronize our system on the utility grid, it is necessary to use a $P L L$. In the literature, several types of $P L L$ are presented [6]. We select the three-phase $P L L$ based voltage also called PLL Park [6]. Its block diagram is shown in Figure 8. The principle of this PLL is to apply the Park transform to the three-phase grid voltages and adjust the qaxis voltage component $\left(V_{q r}\right)$ to zero $\left(V_{q r}{ }^{*}=0\right)$.

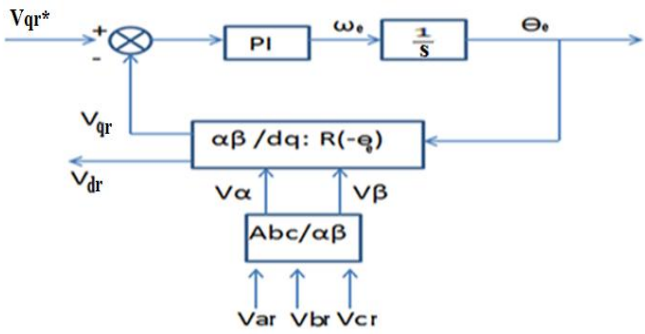

Figure 8. Diagram of the PLL Park

First, the Concordia transform is applied to the grid voltages $\left(V_{x r}\right)$ to obtain the alpha-beta voltages $\left(V_{\alpha \beta}\right)$. Then we do a rotation $R\left(-\theta_{e}\right)$ to obtain dq- voltages $\left(V_{d q r}\right)$ [6]. 
Thus, we obtain (20).

$$
\left(\begin{array}{l}
V_{d r} \\
V_{q r}
\end{array}\right)=\mathrm{V} \sqrt{3}\left(\begin{array}{c}
\cos (\Theta \mathrm{r}-\Theta \mathrm{e}) \\
\sin (\Theta \mathrm{r}-\Theta \mathrm{e})
\end{array}\right)=\mathrm{V} \sqrt{3}\left(\begin{array}{c}
\cos (\Delta \theta) \\
\sin (\Delta \theta)
\end{array}\right)
$$

Where $V=230 \mathrm{~V}$ is the RMS grid voltage, $\theta_{e}$ the estimated angle, and $\theta_{r}$ is the grid voltage angle $\left(\theta_{r}=\omega t\right)$.

The PLL locks when $\theta_{e}=\theta_{r}$. This condition is achieved if the PI controller regulates $V_{q r}$ to zero.

1) Calculation of the PI controller parameters $\left(k_{p 2}, k_{i 2}\right)$ of the PLL

By considering for small values of $\Delta \theta$, the term $\sin (\Delta \theta)$ tends to $\Delta \theta$ [8], we have:

$\Delta \theta=\theta_{r}-\theta_{e}$, In this case, the simplified diagram of the PLL is shown in figure 9.

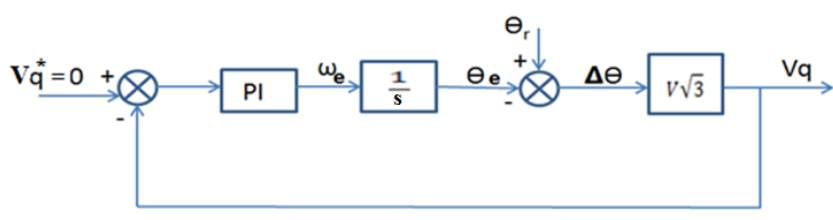

Figure 9. Simplified diagram of the PLL

The transfer function of the parallel PI controller is:

$$
C_{p 2}(s)=k_{p 2}+\frac{k_{i 2}}{s}
$$

According to the figure 9 , the open loop transfer function $(G)$ is the following:

$$
G(s)=\frac{V_{q r}{ }^{*}(s)}{V_{q r}(s)}=-V \sqrt{3} \cdot\left(\frac{k_{p 2}+\frac{k_{i 2}}{s}}{s}\right)
$$

The closed-loop transfer function can be written as:

$$
H(s)=\frac{G(s)}{1+G(s)}=\frac{-V \sqrt{3}\left(k_{i 2}+k_{p 2} s\right)}{s^{2}-V \sqrt{3} \cdot k_{p 2} s-V \sqrt{3} \cdot k_{i 2}}
$$

Using (15) and (23), we obtain (24):

$$
\left\{\begin{array}{l}
k_{p 2}=\frac{-2 z \omega_{i 2}}{V \sqrt{3}} \\
k_{i 2}=\frac{-\omega_{i 2}^{2}}{V \sqrt{3}}
\end{array}\right.
$$

Where $\omega_{i 2}=\frac{1}{T_{i 2}}$ is the cut-off frequency, $t_{i 2}$ is the response time of the system of figure 9 and $z$ is the damping factor. We fixed $t_{i 2}=10 \mathrm{~ms}\left(t_{i 2}<t_{i 1}\right), z=1$ (to eliminate the oscillations) and we obtain $\omega_{i}=100 \mathrm{rad} / \mathrm{s}$. This provides: $k_{p 2}=-0.5$ and $k_{i 2}=-25$.

\section{SIMULATION RESULTS AND INTERPRETATIONS}

\section{1) The decoupled $P Q$ control}

The simulation is done using the Matlab software (Simulink \& SimPowerSystems) by considering the specifications given in table I.

So in order to test the performance of the decoupled $P Q$ control, we set $Q^{*}=0$ and $P^{*}$ is varied on time $(t)$ as follow:

- $\quad$ for $t \in\left[\begin{array}{ll}0 & 2\end{array}\right] \mathrm{s}, P^{*}=3.2 \mathrm{~kW}$

- $\quad$ for $t \in[24] \mathrm{s}, P^{*}=5.2 \mathrm{~kW}$ (maximum power)

- $\quad$ and for $t \in[46] \mathrm{s}, P^{*}=4.2 \mathrm{~kW}$.

This situation is presented in figure 10 .

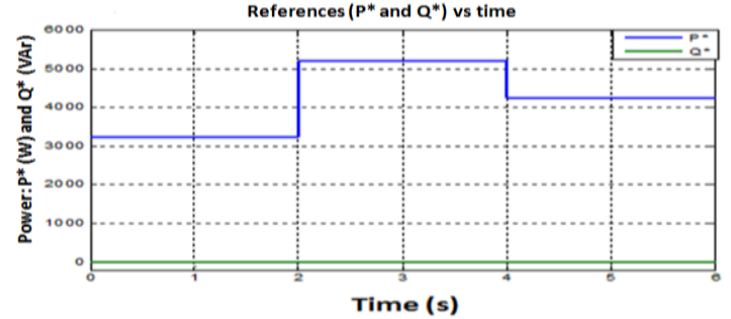

Figure 10. Active and reactive power references $\left(\mathrm{P}^{*}\right.$ and $\left.\mathrm{Q}^{*}\right)$

The simulation results of the decoupled $P Q$ control are shown in figures $11,12,13,14$ and 15 .

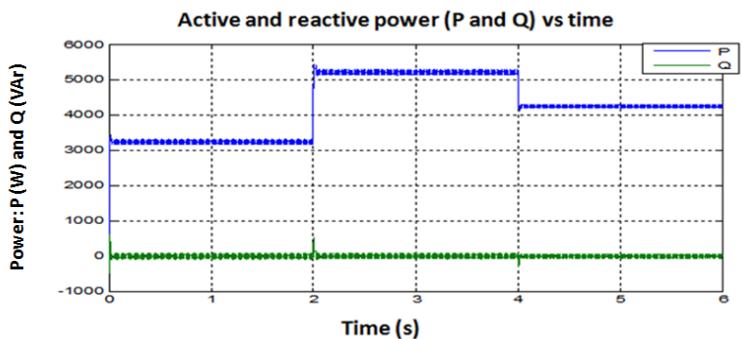

Figure 11. Active and reactive simulated power curves

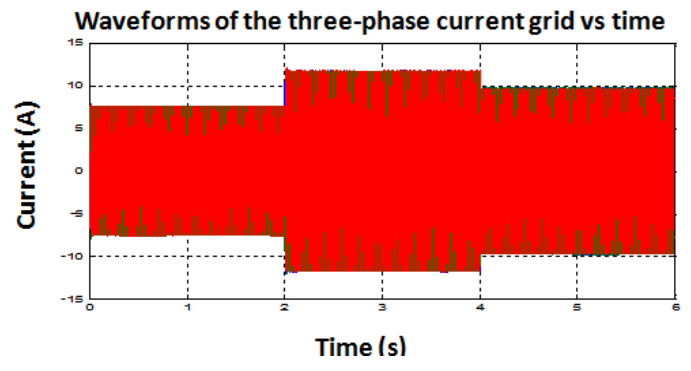

Figure 12. Waveforms of the current grid on the abc frame

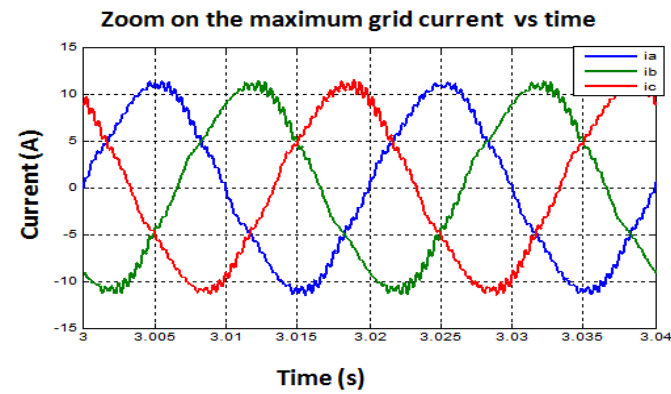

Figure 13. Three-phase grid current when $\mathrm{P}^{*}=5.2 \mathrm{~kW}$

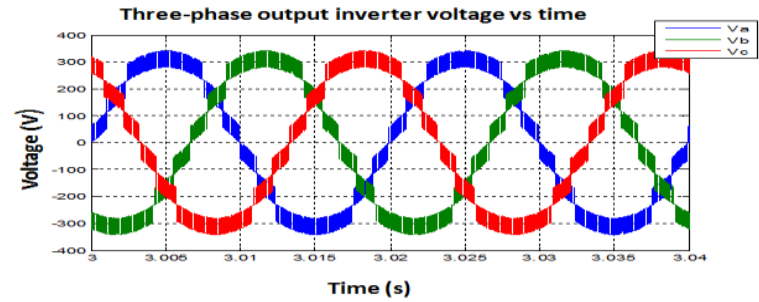

Figure 14. Three-phase output inverter voltage 


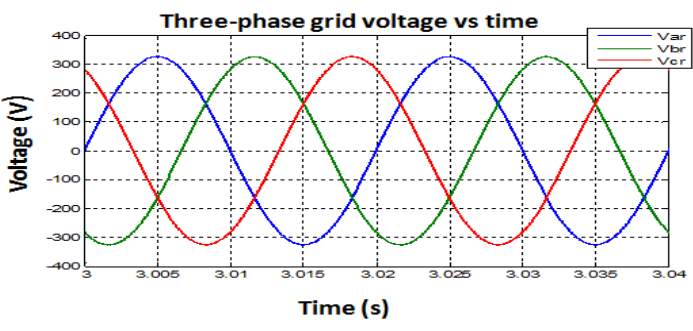

Figure 15. Three-phase grid voltage

\section{2) Interpretation of the results}

Figure 11 shows that the simulated power $(P, Q)$ follows the imposed instructions $\left(P^{*}, Q^{*}\right)$. The reactive power $Q$ (see figure 11) is always equal to zero whereas the active power $P$ vary according to the reference active power $\left(\mathrm{P}^{*}\right)$. The actual current (in the $a b c$ frame) also follows this variation (see figure 12). In these figures, we also observe good behavior of system transients (good system dynamics). Therefore, the decoupled $P Q$ control tracks the references and can be validated. Figure 13 shows a zoom on the current injected into the grid. This current corresponds to the current when the reference power $\left(P^{*}\right)$ is maximum in the interval [2 4] s. We see that this current is practically sinusoidal and smooth. So the L filter fulfills its role. The figures 14 and 15 show the output voltage inverter and the grid voltage respectively.

To connect the inverter and to inject a current into the grid, we must satisfy two conditions: the first is that the inverter output voltage must be greater than the grid voltage. The second condition is that the current injected frequency must be adjusted of the grid frequency.

In the figures 14 and 15 , the maximum amplitude of the voltage inverter is slightly greater than the amplitude of the grid voltage. Therefore, the first condition of coupling to the grid is achieved.

To check the condition of the current frequency matching and grid frequency, we need to synchronize our system with the grid. This is the role of the PLL. Figure 16 shows the superposition of the inverter current curve (current injected into the grid) of the phase $a$ on the simple grid voltage curve of the same phase.

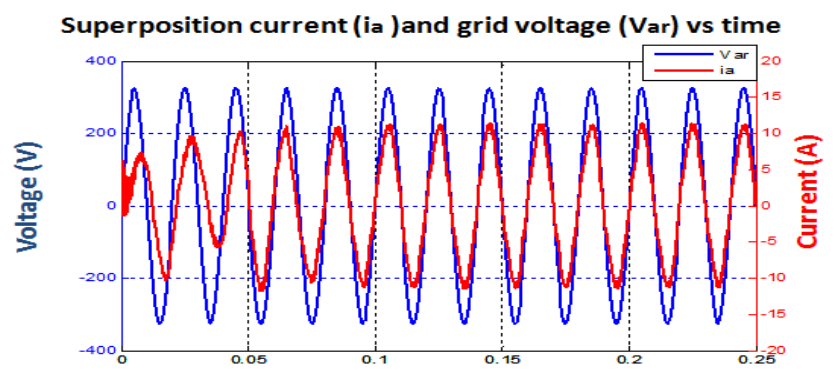

Time (s)

Figure 16. Superposition of the current inverter and grid voltage curves

Figures 16 shows that, at steady state, the current $\left(i_{a}\right)$ and the grid voltage $\left(V_{a r}\right)$ are in phase and have the same frequency. It can be seen that the steady state is reached in $100 \mathrm{~ms}$ whereas the PLL synchronizes the system in less than $80 \mathrm{~ms}$.
Finally, figure 15 shows that the three-phase grid voltage is sinusoidal and smooth. Therefore, our system injects the current into the grid without disturbing it.

\section{CONCLUSION}

The decoupled $P Q$ control used followed the instructions of powers $\left(P^{*}\right.$ and $\left.Q^{*}\right)$. The $P L L$ also managed to synchronize the system in about $80 \mathrm{~ms}$.

The electrical design and simulation results showed the value of the interleaved inverter. The strengths of this inverter is the quality of the waveforms (see figure 14), the reliability of the system (several interleaved cells), the reduction of the output filter volume (see (6)), the improved system dynamics and the simplicity of the control, using of a simple $L$ filter.

However, the disadvantage of the proposed architecture is the number of semiconductor switches used for the MPI fabrication. Fortunately, this disadvantage can be mitigated by the reliability of the system and the low price of components semiconductors (low class).

\section{REFERENCES}

[1] A. Reznik, M. S.-D. (2012). LCL Filter Design and Performance Analysis for Grid Interconnected Systems . Power Electronics and Machines in Wind Application (PEMWA), IEEE , 1-7.

[2] BAYOUMI, E. H. (2015). Three-phase LCL-filter for Grid-connected Inverter Using Cooperative Bacteria Foraging Optimization. Wesas transactions on Systemes and Control, Volume 10.

[3] Fabien, A. (2011). Onuduleur multicellulaire paralèlle à ICT: commande équilibrante, analyse,modélisation, et optimisation des performances CEM: Thèse réalisée au laboratoire SATIE, ENSCACHAN, Cachan, France.

[4] Guepratte, K. (2011). Onduleur triphasé à structure innovante pour application aéronautique (Doctoral dissertation, Université de Grenoble). Thèse, Grenoble.

[5] Nguyen, V. L. (2015). Couplage des systemes photovoltaiques et des vehicules electriques au reseau Problemes et solutions. Université de Grenoble: Thèse de Doctorat de l'Université de Grenoble.

[6] SALIM, M. (2013).Contribution à l'optimisation des installations photovoltaiques par des commandes intelligentes. Batna: Thèse,Université de Hadj Lakhdar, Batna, Algerie.

[7] Xu Renzhong, X. L. (2013). Design and Research on the LCL Filter in Three-Phase PV Grid-Connected Inverters. International Journal of Computer and Electrical Engineering, Vol. 5, No. 3.

[8] Hervé FERAL, T. K. (Janvier 2002). Raccordement d'une éolienne au réseau électrique d'un batiment. Toulouse: Rapport de Projet Long, INP- ENSEEIHT.

[9] Alali, M. A. (2002). Contribution à l'Etude des compensateurs actifs des réseaux électriques basse tension. Doctorat de l'Université du Havre.

[10] R. Marwani, M. Abdelkader and E.Kamel. Connected PV system conrolled by voltage oriented control with MPPT. 16th IEEE Mediteranean Electrotechnical Conference, Yasmine Hammamet, Tunisia: March 2011.

[11] Jean-Paul Ferrieux et François Forest (1999): Alimentation à découpage Convertisseurs à résonance, Principes-composantmodélisation. Livre, bibliothèque de l'ENS-CACHAN, Cachan : 3e edition DUNOD, Paris.

[12] Marwani, Rym. Commande et réailisation d'un système PV racordé au réseau de distribution. Thèse de Doctorat, Faculté des Sciences de Tunis: Juin 2013.

[13] BOUHALLI, N. (2009). Etude et intégration de convertisseurs multicellulaires parallèles. Thèse de Doctorant de l'Université de Toulouse, France. 